described by Herodotus; that some of the tumuli on the eastern shores of the Mediterranean are certainly "as old as the thirteenth century, B.C. : that the practice of burying in tumuli must have existed for many centuries before such tombs could have been constructed; and that the age in which they "were erected was essentially the age of bronze: not only are the ornaments and furniture found in the Etruscan tombs generally of that metal, but the tombs at Mycenæa and Orchomenos were wholly lined with it;" a fact which is the more interesting when we remember that all the metallic objects found in the tumuli round Stonehenge were of bronze.

Again, let us consider the class of monuments which consist of a free dolmen standing on a mound, and surrounded by one or more stone circles. This type is very widely distributed. A Danish example has already been given, Fig. 5. Fig. 4 represents the long barrow at Kennet, near Marlborough, after Dr. Thurman; Fig. 2 is the Dolmen de Bousquet in the Aveyron; lastly, Fig. 7 is a similar monument at Pullicondah, near Madras. These tumuli, though differing in detail, are identical in all essential

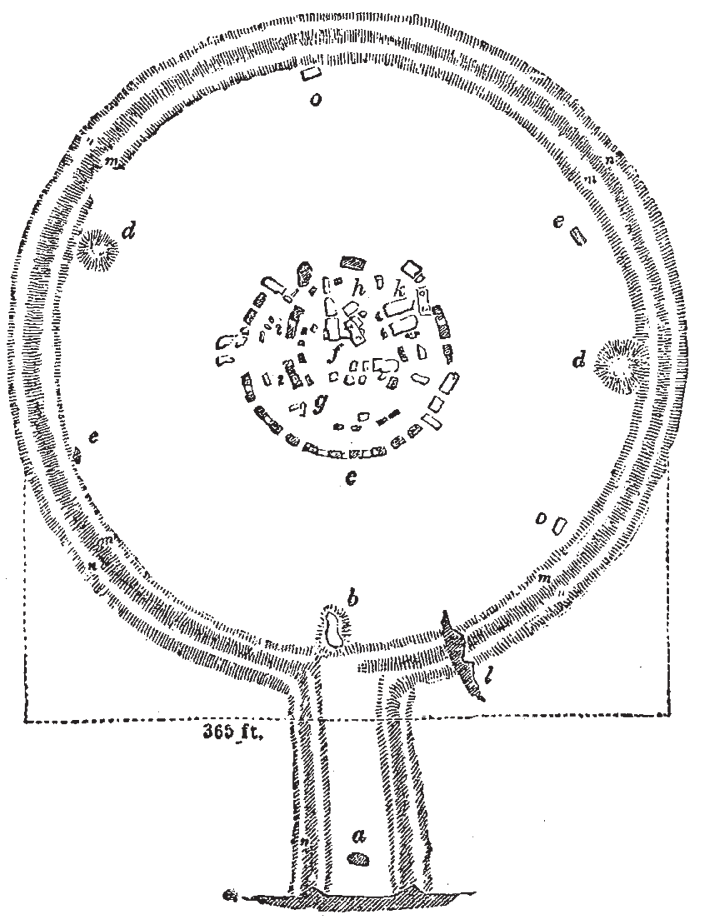

FIG. 8.-General Plan of Stonehenge, from Knight's "Old England."

points. If these monuments all belong to post-Christian times, they must have been erected by very different races of men. Mr. Fergusson, indeed, admits that they are the work of very different races; how then does he account for the remarkable similarity existing between them? He denies that the Celts, Scandinavians, or Iberians were themselves naturally "rude stone builders," and endeavours to remove the difficulty by an explanation which is most important, because it seems to me to involve the practical abandonment of the conclusion, which, as he told us in the preface, is the central feature of his work. This style of art, he says, "seems to have been invented by some pre-Celtic people, but to have been adopted by Celts, by Scandinavians, by British, and Iberian races."

But if Europe was once occupied by a pre-Celtic, megalithic-monument-building race, surely some of our megalithic monuments must be ascribable to that time and race, and we come back therefore to the general opinion of archæologists, that our megalithic monuments belong to very different periods and people, and not all to one race or one epoch.

I cannot now enter into the consideration of the dates to which Mr. Fiergusson ascribes individual monuments; I doubt whether any belong to so recent a period as he supposes : and can only express my surprise at the certainty and confidence which he feels in his own opinions-a certainty sometimes, however, oddly expressed, as, for instance, when he tells us, speaking of the crosses at Katapur, which he considers to be Christian and contemporaneous with a group of neighbouring dolmens, that "their juxtaposition and whole appearance render escape from this conclusion apparently inevitable."

But while I cannot accept Mr. Fergusson's peculiar theories, I cannot conclude without thanking him for the labour and care with which he has brought together a great number of illustrations, and a vast mass of facts, on this most interesting subject. In a review, one naturally dwells on points of difference, but every one must accord to Mr. Fergusson the credit which, in the following passage from his preface, he claims for himself though $I$ would venture to add that the unintentional self-criticism in the latter sentence seems to me not inapplicable. "I have," he says, "spared no pains in investigating the materials placed at my disposal, and no haste in forming my conclusions." His conclusions are, I think, in some cases, hasty and untenable; some seem in. consistent with one another; but no one can deny to his work the merit of being a rich and trustworthy store. house of facts.

JOHN LUBBOCK

\section{THE STUDY AND TEACHING OF MECHANICS}

A LECTURE on this subject, being one of the series of lectures at the College of Preceptors on the Teaching of Physical Science, was given by Prof. W. G. Adams, of which the following is the substance:-

Mechanics treats of the laws of equilibrium and of motion of bodies, and in its widest sense, as the science of energy, must include all branches of Physics, for tho solid, liquid, and gaseous states of bodies are determined by the more or less free motion of their molecules, and heat, light, electricity and magnetism are all different forms of motion. The study of the laws of equilibrium and of visible motion is important, both for their practical applications and because on them are founded the principles of thermo- and electro-dynamics. Before entering on a study of mechanics, students should have a knowledge of algebra and geometry, and on account of the importance of accurate measurement, the elements of trigonometry should also be studied. By a proper method of teaching geometry, boys can be taught to think, and the exact definitions and proofs of Euclid's Elements are better fitted to train the judgmert and the reasoning powers than any less exact system of geometry. The way to teach geometry (and the same remark applics to mechanics) is not to expect boys to get up their Euclid from a book, and to say it off by the aid of a book of figures (a system which has been practised in many schools), but to explain the meaning of and illustrate every proposition, so that boys may understond it. The true method of teaching mechanics is illustrated by the way in which Galileo established the first principles of dynamics, and placed them berore his pupis. Duc weight should be given both to experimental and to rational mechanics, and the best way of bringing the subject before students is to have parallel but distinct courses of experimental and theoretical lectures attended by students at the same time. The practical applications of the subject are important, and some of them of great simplicity. The "Triangle of Forces" may be employed to build up diagrams to represent the thrusts on a jointed 
framework; so that by "Diagrams of Forces" the conditions of stability of loaded structures, and the form and tensions of suspension bridges, could at once be determined, by measurement of these diagrams or by calculation from them. Of the variety of text-books on the subject of mechanics, the teacher should reject books that profess to be adapted for examinations, as well as those which contain gross errors on the laws of friction, or on the inertia of matter and the laws of motion, or on the subject of dynamical units and should select from those which are not liable to such objections.

Competitive examinations may be useful if they are made tests of thorough knowledge; but too often they injure the student who is preparing for them by narrowing his mind, and create a class of dabblers in science, and are worthless for the purpose for which they are intended. Test examinations given to a class on the subject of their lectures are the best tests of the knowledge and progress of the student.

In teaching the laws of equilibrium of liquids and of gases, the same method must be followed as in tarching the laws of equilibrium and of motion of solids; and in addition to lectures and ordinary teaching students should have the opportunity of making experiments and measurements in these subjects in a physical laboratory. Some knowledge of other kindred sciences is recessary before a student can be said to have an intelligent knowledge of the principles of mechanical science. Accurate investigation and experiment show that near the melting and the boiling points the special properties and laws of solids or of liquids are no longer true, and Dr. Andrews has pointed out the existence of a border-land between the liquid and the gaseous states, and has shown that there is no breach of continuity between them. Taking a model, of which three rectangular edges shall represent the pressure, volume, and temperature, the lipper surface will represent the state of the substance, and will explain in what way it is possible to pass from the liquid to the gas without change of state or any sudden change of volume. The ease with which we can conceive of the state of a gas under different circumstances, when we hiave such a model before us, shows the importance of cimploying figures and models to give a boy clear ideas of the propositions of mechanics.

Regarding Mechanics in its wider sense as the Science of Energy, there are three great principles-the Conservation, the Transformation, and the Dissipation of Energy, which have been established, and these principles are illustrated in the conversion of water into steam, in winding up a watch, in the diffusion of gases, in the conduction of heat, in the friction of the tides on the earth, and in the rushing of water down a mountain side. This latter source of energy has been employed in piercing the Mont Cenis tunnel.

'The accuracy of the calculations by which the axes of the two tunnels on opposite sides agreed so completely with one another shows the importance of accurate measurement, and of the correct application of theoretical principles to practice.

These principles of energy tell us that in raising the waters of the ocean to the mountain tops, as much energy must be expended as can be expended by those waters in their return to the ocean, and the atmosphere, acted upon by the solar heat, is the vast air-engine by which these changes are accomplished.

\section{NOTES}

At tise last mceling of the Royal Society the names of the candidates for elotion into the Society were read, in accordance with the statutes, as follows:-Andrew Leith Adams, SurgeonMajor; William Grylls Adams, M.A.; William Aitken, M.D.; Sir Alexander Armstrong, K.C.B., M.D.; Edward Middleton
Barry, R.A.; John Beddoe, B.A., M.D.; Henry Bowman Brady, F.L.S.; Frederick Joseph Bramwell, C. E.; James Brunlees, C.E.; Edwin Kilwick Calver, Capt. R.N.; Alexander Carte, M.A., M.D.; William Chimmo, Commander R.N.; Prof. Arthur Herbert Church, M. A. ; Fredk. Le Gros Clark, M.R.C.S.; Prof. John Cleland, M.D. ; Herbert Davies, M.D. ; Henry Dircks, F.C.S. ; August Dupré, Ph.D. ; Michael Foster, jun., M.A., M.D. ; Peter Le Neve Foster, M.A.; Wilson Fox, M.D.; Arthur Gamgee, M.D. ; Prof. Thomas Minchin Groodeve, M.A.; Townshend M. Hall, F.G.S.; Edmund Thomas Higgins, M.R.C.S. ; Rev. Thomas Hincks, B.A. ; Rev. A. Hume, LL.D.; Henry Hyde, Lieut.-Col. R.E. ; Prof. Wiiliam Stanley Jevons, M.A.; Edmund Charles Johnson, F.R.G.S. ; George Johnson, M.D. ; Prof. Thomas Rupert Jones ; John Leckenby, F.G.S.; Clements R. Markham, Sec. Geog. Soc.; William Mayes, Staff-Comm. R.N. ; Edmund James Mills, D.Sc. ; Thomas George Montgomerie, Major R.E.; Robert Stirling Newall, F.R.A.S. ; Edward Latham Ormerod, M.D. ; Francis Polkinghorne Pascoe, F.L.S. ; Prof. Oliver Pemberton; Rev. Stephen Joseph Perry; John Arthur Phillips, F.C.S.; Bedford Clapperton T. Pim, Captain R.N. ; William Overend Priestley, M.D.; Charles Bland Radcliffe, M.D.; Edward John Routh, M.A.; George West RoystonPigott, M.D.; William Westcott Rundell ; William James Rus. sell, Ph.D.; Osbert Salvin, M.A. ; Harry Govier Seeley, F.L.S.; Alfred R. C. Selwyn (Geol. Survey, Canada); Peter Squire, F. L.S.; George James Symons, V.P. Met. Soc.; Edwin T. Truman, M.R.C.S.; Wildman Whitehouse, C.E.; Henry Woodward, F.G.S.; Archibald Henry Plantagenet Stuart Wortley, Lieut* Col.

The EARL OF LONSDALE, whose death is recorded this week, was the father of the Royal Society, his election having taken place sixty-two years ago, in 1810 . This honour now devolves on Sir Henry Holland, elected in $18 \times 5$.

THE death is announced, on the 3 rd inst., of Dr. A. B. Granville, F.R.S., at the age of 88 . He was one of the oldest Fellows of the Royal Society, having been elected in 1817 , and was member of a large number of foreign learned societies.

WE are very glad to be able to state that intelligence has just been received from Prof. Huxley that his health has already been greatly renovated by the pure air of Upper Egypt. He wrote from Thebes, and was then contemplating a visit to Assouan, from which he would probably have returned to Thebes before this.

SIR WrLliam Thomson has accepted the office of President of the Geological Society of Glasgow.

The Radcliffe Travelling Fellowship at Oxford has been awarded to Mr. F. H. Champneys, B.A. of Brasenose College. This Fellowship is of the annual value of $200 l$, and tenable for three years, provided the Fellow does not spend more than eighteen months within the United Kingdom.

The President of the Quekett Microscopical Club will hold a soirée, on Friday evening, March I5, at University College.

DR. Lrebreich, the eminent ophthalmist, of St. Thomas's Hospital, delivered a lecture at the Royal Institution on Friday evening last, on certain faults of vision, with special reference to Turner and Mulready. The later "aberrations" of Turner's style he attributed to a physical change in the refractive power of the eye, by which illuminated points were converted into illtminated lines. The change of manner in Mulready's later pictures he accounted for, in like manner, by increasing yellow degeneration of the crystalline lens. We hope in a future number to give a report of the lecture. 